$\triangle C T A \mathbb{N E O P H I L O L O G I C A}$

UDK: 821.111.09-31Hardy T.

DOI: 10.4312/an.51.1-2.127-135

\title{
The Circus and the Deadly Child: Ruptures of Social Code in Jude the Obscure
}

\section{Tobias Wilson-Bates}

\begin{abstract}
Thomas Hardy's Jude the Obscure has frequently been read as Hardyss social critique of marriage, class, and systemic education. Readings of the novel in this critical tradition have a tendency to simplify the text into an allegory emergent from Hardy's own biography. I seek to destabilize these readings by instead engaging with the text as one not concerned with institutions but rather the underlying social codes that give them coherence. By pairing Mikhail Bakhtin's concept of speech and counter speech with Lee Edelman's queer critique of child-centered futurity, I offer a new reading of the novel that privileges codes and legibility as central to the novel's critical project.
\end{abstract}

Key words: Thomas Hardy, Jude the Obscure, Victorian fiction 
At various moments in Jude the Obscure, the reader is placed in the position of the shocked spectator. Indeed, sudden violence and harsh disillusion are two of the text's most remarkable features. Traditionally, these moments, where implicit social violence becomes explicit, are generally read as exclamation points to the work's criticism of specific social institutions. This paper seeks to destabilize such claims by revisiting the novel's most bizarre scenes. The first, when a peculiar band of market folk spring into violence during a public meeting, and, the second, when Little Father Time murders his siblings before committing suicide. These scenes that interrupt the social moment and scatter the preceding discourses of the novel provide insight into the greater nature of the novel's exploration; namely, that it is not social institution that is at fault for the misery of the text, but society's deeper inability to formulate logics capable of accounting for the world at large.

I begin my reading by quoting a displaced fragment of text within Hardy's narrative: "The farcical yet melancholy event was the beginning of a serious illness for him; and he lay in his lonely bed in the pathetic state of mind" (240). This passage, removed from its context in the novel, seems as if it could be applied to almost any moment in Jude. The scene is a reaction shot to a traumatic moment of unexpected reversal. The reader is probably inclined to think of Jude Fawley in this moment, perhaps in the long still section of the novel following the deaths of his children and Sue's departure for religion and for Phillotson. However, this is an earlier moment and a different man. Here we are actually reading Phillotson's reaction, not to Sue's departure with her lover, but to a scene of carnivalesque mayhem that erupts at the town council meeting when Phillotson argues for the private nature of his marital affairs.

What's telling about this scene, and the school teacher's reaction to it, is that Phillotson does not seem to take ill because of the council's verdict on his actions or even his consequential dismissal. Phillotson's conversations with Gillingham leading up to the meeting have prepared him for just this oppositionary logic of right and wrong: "' $[\mathrm{B}] \mathrm{y}$ resigning I acknowledge I have acted wrongly by her; when I am more and more convinced every day that in the sight of Heaven and by all natural, straightforward humanity, I have acted rightly"' (238). Through the first half of the meeting, Hardy describes this simple logic playing out quickly. Phillotson "contended...that the matter was a domestic theory which did not concern them," followed by the townspeople's response that "the private eccentricities of a teacher came quite within their sphere of control, as it touched the morals of those he taught" (239). Here then we have quick and clean articulation of the identity of the individual posed against the landscape of the social. Phillotson's position as a perpetuator of normative social identities makes him a particularly apt figure for this play of personal versus social agency. But as we learn through the ostracizing of Jude and Sue, no such position is necessary for becoming an object of exclusion. 
Phillotson appears preeminently aware of these logics. As a disenchanted scholar and school teacher, he is situated in a privileged position of knowledge concerning his social context. In attempting to become a scholar and failing, he has already come up against the social apparatus writ large, and in structuring the experiences of his faceless students (he has no particular memory of Jude despite the intimate scene from earlier life and the brief educational correspondence), he is aware of himself as a participant in its reproduction. At play, then, is the concept of the social code. As Jude passionately states to Sue only a few pages before the scene in question, "I have sometimes thought, since your marrying Phillotson because of a stupid scandal, that under the affectation of independent views you are as enslaved to the social code as any woman I know!" (232). ${ }^{1}$

It's worth reflecting on how the idea of "code" operates particularly as an organizing concept in these moments and makes explicit other moments of the text that display a concern with social coding. The idea of the code allows the reader to work in two directions simultaneously. First, there is a totalizing tendency in choosing code over tradition or law because its bare structuralism allows for a sort of all-encompassing multi-valence. When Jude accuses Sue that she is bound by social code, the statement is effective because it works beyond the simple situation of her marriage and extends to the implicit socio-cultural apparatus that exerts pressures of class, propriety, and mobility throughout the text. The natural modern connection to code as the underlying structure of digital media is a compelling parallel that might be used to imagine how the term operates. Code constructs all that is possible in the virtual landscape, and beyond expressing what is, it also underlies the logic of all that could possibly be.

The second value of code is that the singularity of the term allows for meaning to operate on the specific as well as the abstract level. Code is at once the entire system and an instance within the system. Jude's declaration about Sue's enslavement to social code signals outwards to the social scene while at the same time referencing the particularities of the marriage institution. In this way, the concept always potentially contains its own interplay of individual articulation and social response.

Mikhail Bakhtin approaches the social code from the level of language. Speech, as an always-socially-situated phenomena, consistently indicates its existence within its larger social context, even at the level of the word. The word, for Bakhtin, never exists alone but always signals towards other words and contexts and "encounters an alien word not only in the object itself: every word is directed toward an answer and cannot escape the profound influence of the answering

1 This use of "code" as a metaphor for underlying social structures echoes an earlier moment where Phillotson is separated from Sue due to Code, "It was part of his duty to give her private lessons in the evening, and some article in the Code made it necessary that a respectable, elderly woman should be present at these lessons, when the teacher and the taught were of different sexes. (99) 
word that it anticipates" (28). Programmed into social discourse is this complex oppositionary logic of speech and counter-speech.

With this basic framework in mind, I'd like to return to the scene addressed earlier where Gillingham and Phillotson discuss the issue of individual morality in relation to the social scene. The conversation moves back and forth over the course of several pages and eclipses several days in narrative time. The end result is a final argument and opposition where Phillotson declares that the committee's sentiment "doesn't affect me in my public capacity," only to have Gillingham counter that as an issue concerning youth and "the morals of the town," Phillotson's position is “indefensible" (238).

It's necessary to summarize the scene carefully because, without an understanding of this basic dialogue, the odd following scene is easily misinterpreted. When Phillotson speaks out at the public meeting, he is already completely aware of the speech and counter-speech that will play out given the social codes involved. Phillotson argues for conduct performed along the moral guidelines of universal empathy while the community responds via the moral concerns of specific social situation. Hardy doesn't even transcribe the speech of this interaction, writing in a brief paragraph, "All the respectable inhabitants and well-to-do fellow-natives of the town were against Phillotson to a man" (239). Given that the reader has already dialogically negotiated the logics of this scenario, it makes perfect sense that the scene is so abbreviated.

However, what follows next is one of the more suddenly surreal explosions of nonsensical violence in all of Hardy's writing. None of the preceding scene warrants environmental description, meaning that the reader is left to imagine where and how the public meeting has been conducted. One might envision some sort of open public forum with seating where some vaguely middle-class men and women sit with expressions of disapproving skepticism while Phillotson pleads his case. However, this vision is punctured suddenly by an element even the narrative itself seems surprised by: "But, somewhat to his surprise, some dozen of more champions rose up in his defence as from the ground" (239). This moment of confusion seems to bridge a gap that forms simultaneously between two levels of code. First, the social code of the town within the novel is interrupted. The speech/counter-speech rehearsed by Phillotson and Gillingham before the meeting and the repetition of the same speeches within the meeting are suddenly broken by an unexpected "other." Second, the reader's relation to the narrative scene itself is destabilized. Hardy has either left out many of the participants in this pivotal scene until they begin to speak or the characters did not exist at all until they suddenly erupt into the middle of the town's social life.

To rephrase, the reader is as absolutely unprepared for the champions from the ground as Phillotson. One might even surmise that the faceless "respectable 
inhabitants" are likewise astonished to suddenly find themselves in the company of amoral itinerants. Hardy's description of Phillotson's defenders only enhances the absurdity of the scene:

The body included two cheap-jacks, a shooting-gallery proprietor and the ladies who loaded the guns, a pair of boxing-masters, a steam-roundabout manager, two travelling broom-makers, who called themselves widows, a gingerbread-stall keeper, a swing-boat owner, and a 'test-your-strength' man. (239)

The interjected individuals, already an oddity in their moral stand, are rendered even more bizarre by the carnivalesque array of their professions. How does one not notice being in the same room with a 'test-your-strength man'? What does it mean that two of the women "call themselves widows"? Connected as they are by fairs and markets, does this group constitute another community or merely a chance meeting of itinerant professionals?

Their position in relation to Phillotson's moral stand is also unclear. They rise up in his defense, but is it in accordance with the school teacher's "natural charity" or is it in some other mode of critique? This list in its intertextual possibilities alone is remarkable. The steam-roundabout manager brings to mind the opening scene of "On the Western Circuit"; the shooting gallery keeper rings of Dickens' George Rouncewell; and the gingerbread-stall keeper almost seems a premonition of Jude's future occupation. The women performing widowhood also seem significant in their claim. What is to be gained by claiming to be widows? Are they on the move despite marriage like Arabella in Australia, or are they in some other mode of relationship that requires a cover-up?

These questions and considerations are for the most part unanswerable or absurd, but that is just what makes the entire situation interesting. Hardy moves from this recitation of curious professionals into an even more bizarre scene of madcap violence:

[T]hey expressed their thoughts so strongly to the meeting that issue was joined, the result being a general scuffle, wherein a blackboard was split, three panes of the school-windows were broken, an inkbottle was spilled over a town-councillor's shirt-front, a church-warden was dealt such a topper with the map of Palestine that his head went right through Samaria, and many black eyes and bleeding noses were given, one of which, to everybody's horror, was the venerable incumbent's, owing to the zeal of an emancipated chimney-sweep, who took the side of Phillotson's party. (239)

This scene does work on a number of narrative levels. First, it is the most active sequence of the entire novel. The other moment of unexpected rupture, the 
murder-suicide of the children, happens outside of the reader's vision and involves significantly less action. The climactic conflict also finishes off the backwards logic of the overall sequence. It's only when the school-windows start breaking that the reader realizes the entire series of events is actually taking place inside the schoolhouse. Setting leaps into existence just like Phillotson's supporters, and even more characters enter the fray as we're introduced to a chimney-sweep omitted from the earlier list of combatants. The social logic of the town and the narrative logic of the novel seem to scatter confusedly at this moment.

Despite the riotous hullaballoo, the narrative voice remains distanced and impassive throughout, at one point pausing the action to show the reader at what position the church-warden's head enters a map of Palestine. It is as if, at this moment of most intense immediate experience, the reader is positioned at a great distance from the text and forced into a heavily mediated relationship of narrative vision. This mediation of detached narrative voice is entertaining as it contrasts with the wildness of the events described, but the curious distance from a heavily emotional context also sets a precedent for the following scene and the even darker events thereafter. Emphasizing the narrator's coolness is Phillotson's crippling inability to come to terms with the event.

It is my argument that Phillotson's consequential illness has nothing at all to do with the town's rejection of his case or the loss of his position, and everything to do with the fantastic eruption of the carnivalesque moment in the middle of his premeditated social dialogue. Hardy describes Phillotson's reaction to the event at length, beginning with, "The farcical yet melancholy event was the beginning of a serious illness for him; and he lay in his lonely bed in the pathetic state of mind of a middle-aged man who perceives at length that his life, intellectual and domestic, is tending to failure and gloom" (240). There is a harsh divergence here, once again, between the position of the narrative voice and that of the character described on the page. Phillotson clearly does not see the event as farcical, but rather as a death-knell to his already strained ability to cope with the world at large.

Of course, this "world at large" for Phillotson has a very specific meaning. It is a world where identifiable subject-positions are definitively mapped into the social landscape. Thus, when Phillotson eventually changes his position concerning his wife, it is not to some new understanding of the situation but rather a reversion to the opposite extreme of his former stance. Hovering above this back-and-forth is the disconnected narrator, who seems detached from either extreme of the social logics exemplified in Phillotson's behavior. This position of exteriority implicitly poses the question of what the overarching voice of the novel proposes, a question that becomes that much more poignant when the novel represents its most notable scene of pain and trauma. 
Throughout the critical history of Jude, the narrator is collapsed with the critical social voice of Hardy. Critics assume that the narrative perspective of the novel is simply a cipher for how Hardy responds to criticism or proposes social critiques of marriage since Hardy himself is not dissimilar from the class and educational status of his protagonist. The novel is often shaped into a biographical narrative involving Hardy's position on reader response to his tragic vision, criticism of marriage as an institution, or the anger of a lower-class autodidact writing towards a system of judgmental elitism. ${ }^{2}$ Each of these formulations demands an oppositionary logic that identifies the narrator by defining it against society. One of the earliest and most cited responses to the novel, Margaret Oliphant's "The Anti-Marriage League," sets up the novel as a series of social oppositions at the level of novel and character. What's most interesting about the reading that sees Jude as "a puppet flung about between them by two women-the fleshy animal Arabella and the fantastic Susan"-is that it solidifies discourses surrounding the novel into the paths they generally follow thereafter (306). Whether later critics agree with Oliphant that Hardy preached an indecent doctrine of "hideous circumstance" or felt that Hardy's intentional perversity signaled more complex social claims, there has been a tendency to see the novel as pedantically trumpeting a monologic social agenda (305). ${ }^{3}$

This reading requires a certain amount of willful exclusion of the elements of the text that don't fit into comfortable binaries, which is especially troubling since the text itself problematizes the possible efficacy of oppositional logic at its most climactic moments. The impossibility of reading the text's social aims as singular, so explicit in the public meeting, echo in the figure of Little Father Time. The morose child with the paradoxically allegorical name splinters novelistic themes and the unity of the plot in his character and actions. He is at once young and ageless, allegorical past and "beginning of the coming universal" (326). Furthermore, his monotone sadness fashions him into a kind of closed-off Bartleby in the social schematic of the novel. It's unclear whether love can affect him, if his sadness stems from a bad marriage, a non-marriage, or a colonial upbringing. Like Phil-

2 A couple of examples of scholars that reinforce this reading include Walter Gordon who writes in his article "Father Time's Suicide Note in the Jude the Obscure" that "Father Time is surely a thinly veiled persona for Thomas Hardy himself" (298) and Alex Moffett who writes in his "Memory and Crisis of Self-Begetting in Hardy's Jude the Obscure" that he does not wish "to contest Hardy's class-based critique of, in Tim Dolin's words, "the ideological bias of the notion of individual change operating within societal stability" (86)

3 A peculiar result of reading the novel as pure social commentary is the repeated appearance of the text in legal discourse including the relatively recent articles "Unwilling Fathers and Abortion: Terminating Men's Child Support Obligations" in The Modern Law Review (2003), and, "So Young and so Untender': Remorseless Children and the Expectations of the Law" in Columbia Law Review (2002). 
lotson's defenders, he seems to simply rise from the ground and, like Phillotson, the defense for his crime seems to be one of natural charity.

Little Father Time appears as a continuation of the nineteenth-century unwanted child tradition, evoking his long line of Oliver Twist-like predecessors as he trudges alone through the street towards another temporary home. However, it's deeply unclear what cause he champions or what social ills he represents. In fact, his apositionality forecasts an issue that Lee Edelman later confronts in relation to the modern apolitical child. In his book No Future, Edelman tackles the issue of identity as it's determined through opposition in the normative social scene. Edelman describes the Child as "the emblem of futurity's unquestioned value" and proposes a queer oppositionality that stands against the very "logics of opposition" as such (4). This difficult formulation, Edelman states,

suggests a refusal...of every substantialization of identity, which is always oppositionally defined, and, by extension, of history as linear narrative ... in which meaning succeeds in revealing itself-as itself-through time. Far from partaking of this narrative movement toward a viable political future, far from perpetuating the fantasy of meaning's eventual realization, the queer comes to figure the bar to every realization of futurity, the resistance, internal to the social, to every social structure or form. (4)

Edelman's argument points towards the inability of oppositionary social code to account for the entirety of the social scene. The inadequacy of the social code does not lie in its structures, but rather in its very concept. In light of this line of argumentation, Jude may be re-imagined as a critique of foundational social logics rather than a criticism of social institutions such as marriage, education, and religion.

\section{REFERENCES}

Bakhtin, M. M., and Michael Holquist. The Dialogic Imagination: Four Essays. Austin: University of Texas, 1981.

Duncan, Martha G. "'So Young and so Untender": Remorseless Children and the Expectations of the Law." Columbia Law Review 102.6 (2002): 1469-526.

Edelman, Lee. No Future: Queer Theory and the Death Drive. Durham: Duke UP, 2004.

Gordon, Walter K. "Father Time's Suicide Note in Jude the Obscure." Nineteenth-Century Fiction 22.3 (1967): 298-300.

Hardy, Thomas. Jude the Obscure. New York: Oxford UP, 2002. 
Moffett, Alex. "Memory and the Crisis of Self-Begetting in Hardy's "Jude the Obscure"” Pacific Coast Philology 39 (2004): 86-101.

Sheldon, Sally. "Unwilling Fathers and Abortion: Terminating Men's Child Support Obligations?” The Modern Law Review 66.2 (2003): 175-95.

Tobias Wilson-Bates School of Literature, Media and Communication Georgia Institute of Technology tgbates@gatech.edu

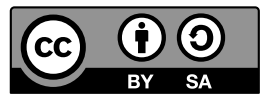

\section{Cirkus in smrtonosni otrok: Razkroj družbenega koda v romanu Jude the Obscure}

Jude the Obscure Thomasa Hardyja je bila pogosto interpretirana kot družbena kritika zakona oziroma poroke, razreda in sistemske izobrazbe. Takšna branja $\mathrm{v}$ tej kritiški tradiciji pa vendarle poenostavljajo tekst v alegorijo, ki izhaja iz Hardyjeve lastne biografije. Avtor članka želi destabilizirati takšne interpretacije in se ukvarja s tekstom, ki naj se ne bi ukvarjal z institucijami, marveč bolj z relevantnimi družbenimi kodi, ki jim omogočajo koherenco. Ob uporabi Bakhtinovega koncepta govora in protigovora s queerovsko kritiko prihodnosti, ki naj bi bila osredinjena na otroka, avtor ponuja novo branje, ki bolj temelje na kodu in berljivosti, ki je po njegovem mnenju osrednjega pomena $\mathrm{v}$ kritiškem projektu romana.

Ključne besede: Thomas Hardy, Jude the Obscure, viktorijanska proza 